\title{
IFAS Community Development: Identifying Local Power Structures, The Positional Approach 1
}

\section{A. Brennan²}

This paper is part of a series of discussions on community development. This series includes specialized papers on leadership development, civic engagement, community action, and other topics important to the development of community.

\section{Introduction}

In the process of community development, it is important to identify positions, organizations, and individuals of power. All types of power can serve as a source of empowerment for local collective action or in more negative settings as a significant obstacle to the emergence of community agency, or the capacity for local of communities to act (Hyman, et al., 2001; Brennan, 2006). There are several ways that extension and other change agents can identify these power structures. One useful method is the positional approach.

\section{The Positional Approach}

The first and most common approach for assessing local power focuses on the individuals who hold formal positions in the major economic, social, governmental, political, cultural, and religious institutions. There are at least three general definitions of leaders to keep in mind:

- Visible leaders. People assigned approximately the same amount of power by other leaders and nonleaders. These people occupy positions of power perceived and known by members of the community at large. Included are political leaders (i.e., mayors, county commissioners, senators), and economic leaders (i.e., CEOs, administrators, union presidents).

- Concealed leaders. People assigned more prestige by leaders than non-leaders. These are often the "people behind the scenes" who hold enormous sway. They exercise their power within the leadership circles or elite power groups. They are often not recognized by members of the community at large. Included in this group are people with social or economic clout and political positions which rarely change ownership (i.e., county and city managers).

- Symbolic leaders. People assigned more prestige by nonleaders than leaders. They do not wield nearly the power or influence in the community as the community at large thinks they do. Often included in this group are religious leaders or

1. This document is FCS9256, one of a series of the Family Youth and Community Sciences Department, Florida Cooperative Extension Service, Institute of Food and Agricultural Sciences, University of Florida. Original publication date July 25, 2006. Visit the EDIS Web Site at http://edis.ifas.ufl.edu.

2. M. A. Brennan, assistant professor, Department of Family, Youth and Community Sciences, Cooperative Extension Service, Institute of Food and Agricultural Sciences, University of Florida, Gainesville, FL, 32611.

The Institute of Food and Agricultural Sciences (IFAS) is an Equal Opportunity Institution authorized to provide research, educational information and other services only to individuals and institutions that function with non-discrimination with respect to race, creed, color, religion, age, disability, sex, sexual orientation, marital status, national origin, political opinions or affiliations. U.S. Department of Agriculture, Cooperative Extension Service, University of Florida, IFAS, Florida A. \& M. University Cooperative Extension Program, and Boards of County Commissioners Cooperating. Larry Arrington, Dean 
individuals representing specific segments of the population (i.e., racial/ethnic groups, gender groups).

\section{Assumptions of the Positional Approach}

The positional approach for identifying power is based on several assumptions. Included are the beliefs that:

1. Power lies in the important positions of formal community organizations;

2. Those holding these positions make the important decisions; and

3. Those in these positions control important local resources.

\section{Procedures for Identifying Positional Power}

To identify leaders and power holders through this method, a series of steps can be taken. Included are:

1. Identify relevant positions. This can be done through a review of government and business directories, local phonebooks, or state/local websites;

2. Compile a list of names or develop a directory of leaders; and

3. Maintain an accurate list by reviewing and updating at least on a yearly basis.

\section{Types of leaders identified}

This approach primarily identifies visible leaders involved in both public and private organizations. Typically the following types of leaders are identified:

1. Elected government officials;

2. Appointed political officers and higher level civil servants (agency heads);

3. Corporate executives, directors, and administrators;
4. Administrators of service and nonprofit groups; and

5. Office holders in member-oriented organizations (unions, fraternities).

\section{Advantages and Disadvantages of this Method}

As with all methods for assessing local power, this method has distinct advantages and disadvantages. When using this method advantages to keep in mind are:

1. This method focuses on visible, easily identified leaders;

2. Identifying leaders and power holders is done at little or low cost;

3. Most publicly accessible lists/directories often represent a good cross-section of community leaders; and

4. Lists/directories provide insights into the potential roles leaders play in other community development activities.

Correspondingly some of the disadvantages of this method are:

1. This method does not identify informal or hidden leaders;

2. It assumes that those identified actually achieve or use their potential power; and

3. This method tends to ignore the difficulty of determining which positions hold power in making specific community decisions.

\section{References and Suggested Reading}

Brennan, M. A. (2006). Identifying Local

Power Structures to Facilitate Leadership and Community Development. Gainesville, FL:

Cooperative Extension Service, Institute of Food and Agricultural Sciences, University of Florida. EDIS. Publication number: FCS 9238/FY816.

Boulding, K. (1989). The Three Faces of Power. Sage Publications. 
Hyman, D., J. McKnight, \& F. Higdon. (2001).

Doing Democracy: Conflict and Consensus Strategies

for Citizens, Organizations, and Communities. Erudition Press. 